\title{
Philosophy and Practice of Education for Sustainable Development in Ukraine: On the Example of Secondary Education in the Dnipropetrovsk Region
}

\author{
By Olha Vysotska1, Serhii Rieznikov², Elena Rohova ${ }^{3}$, Oleksandr Vysotskyi ${ }^{4}$, \\ Maryna Vatkovska ${ }^{5}$
}

\begin{abstract}
The article reveals the features of introducing education for sustainable development in Ukraine, its theoretical basis and practical implementation on the example of Secondary Education in the Dnipropetrovsk region. The importance of forming an integrated developing educational environment based on the principles of education for sustainable development is proved. It determines the interdisciplinarity of the content of education for sustainable development, its high potential in creating a new type of educational environment. Methods and approaches of forming the values of sustainable development as important components of the development of life competencies of the individual are revealed.
\end{abstract}

Keywords: education for sustainable development, integration, educational environment, integrity, personality

\section{Introduction}

Increasing the economic component of human life became a destructive force for the biosphere and humans at the end of the XX century. The need to form a balanced model for the development of civilization, which would be safe for the environment, turned out to be obvious. An attempt to implement such ideas is the strategy of sustainable development, which is currently the leading strategy for the socio-economic development of humanity as a whole.

The strategy of sustainable development was the result of greening scientific knowledge, as well as their adaptation to the socio-economic needs of humanity. The transition to a new model (strategy) of sustainable development has become a natural reaction of the world community to modern global problems. Humanity is faced with a growing contradiction between its increased needs and the inability of the biosphere to provide for them without collapsing. At the same time, not only the satisfaction of vital needs and

| ${ }^{1}$ D.Sc. (Philosophy), Associate Professor, Head of the Philosophy Department of Communal institution of higher education «Dnipro Academy of Continuing Education» of Dnipropetrovsk Regional Council

${ }^{2} \mathrm{PhD}$ (Philosophy), Docent of the Philosophy Department of Communal institution of higher education «Dnipro Academy of Continuing Education» of Dnipropetrovsk Regional Council

${ }^{3} \mathrm{PhD}$ (Philosophy), Professor of the Philosophy Department of Communal institution of higher education

«Dnipro Academy of Continuing Education» of Dnipropetrovsk Regional Council

${ }^{4}$ D.Sc. (Political Science), PhD (History), Professor, Professor of the International Relations Department, Oles

Honchar Dnipro National University

${ }^{5} \mathrm{PhD}$ (Philosophy), Professor of the Philosophy Department of Communal institution of higher education

«Dnipro Academy of Continuing Education» of Dnipropetrovsk Regional Council 
interests of future generations of people, but also the very possibility of their existence, is threatened.

Education and values are essential for promoting sustainable development ideas. Values can be shared with children and adults through educational tools. A large number of directions for implementing education for Sustainable Development are available in Ukraine today. The authors have been working on advanced education for sustainable development for about 10 years. The authors' research was carried out in the course of experiments that covered about 100 schools and 40 preschool educational institutions in the Dnipropetrovsk region. These are the research experiments «Advanced Education for Sustainable Development» (2009-2014) and «Integrating the content of advanced education for sustainable development into the educational process» (2015-2020). The task of the experiments was to create conditions for the most effective socialization of the child based on the principles of advanced education for sustainable development. This provided primarily for increasing the level of self-responsibility of the individual in the development of a sustainable lifestyle, the formation of stable life habits, a general consumer culture based on the principles and ideas of sustainable development of both children and adults (parents, teachers) by improving educational programs, extracurricular educational work, and social project activities.

The main purpose of this article is to reveal the features of the introduction of education for sustainable development in Ukraine, to determine its theoretical basis and practical implementation on the example of the development of secondary education institutions in the Dnipropetrovsk region.

\section{Literature Review}

The theoretical basis of the research is made up of the works of S.Adelman (2018), A.Antunes, \& M.Gadotti (2005), A.Barrable (2019), M.Battiste, (1998), C.Black (2017), M.Bonnett (2007; 2013; 2015), R.Engelman, (2013), J.Fien (2010), E.Fromm (2010), H.Glasser (2004), A.G.Gough, \& I.Robottom (1993), S.Gough, \& W.Scott (2007), J.Gray, \& P.Curry (2016), B.Jickling (1994), H.Spork (1998), C.O.Jogwu (2010), R.Kahn (2010), P.Knudtson \& D.Suzuki (1992), H.Kopnina (2012; 2013; 2014; 2015; 2016; 2018; 2019; 2020), L.J.Kotze, \& D.French (2018), D.LaChapelle (1991), W.McDonough, \& M.Braungart (2002), G.W.Misiaszek (2015), D.Molina-Motos, (2019), D.Orr (1994), A.Schweitzer (2005), M.D.Sitka-Sage, S.Blenkinsop, \& L.Piersol (2017), H.Washington (2018). They made it possible to significantly assess the current state of conceptual development of education for sustainable development.

\section{Data and Methodology}

The main hypothesis of the study was the understanding that the systematic integration of sustainable development ideas will lead to significant changes in the worldview of children and adults, change their life habits and attitude to the environment. To implement this hypothesis, the method of end-to-end education for sustainable development was introduced. It provides for the inclusion of ideas of sustainable development in the content of more curricula in schools in the Dnipropetrovsk region of 
Ukraine, conducting active educational work among children, youth, their parents and teachers.

Education for sustainable development is based on the idea of creating conditions for balanced relationships in the "Human - Nature - Society" system, based on the general principles of sustainable development. The key principle is the principle of compatibility of actions, when the teacher refuses to formally transfer knowledge, and the student from passive listening, moving to active joint activities aimed at preserving the environment, harmonizing relations between people, forming a responsible attitude to their own actions and socially significant values.

When teaching subjects, teachers who participated in the experiment used the method of "productive thinking" proposed by E. Fromm. This author believed that only through a holistic perception of the phenomenon is its productive cognition possible (Fromm, 2010). In other words, the structures of an objective scientific picture of the world should actually be based not on a mechanistic, value-neutral understanding of phenomena and objects in their fragmentary vision (for example, a separate understanding of physical, chemical or biological aspects), but on an interested, value-based and emotionally colored perception of nature as a certain mobile integrity. Interesting approaches to understanding natural phenomena are also the ethics of "reverence for life" by A. Schweitzer and "biophilic ethics" by E.Fromm, which focus on the concept of «living» or «life», pointing out the uniqueness, incompleteness and potential unmanageability of living nature" (Fromm, 2005). It is the reverence for life as such that forms a world - and life-affirming position, which allows a person to have a value-emotional attitude to life as such, without contrasting the natural and spiritual, more valuable or less valuable in each manifestation of life [Schweitzer, 2005].

The authors conducted primary and secondary quantitative and qualitative studies to achieve the research goals. We tested the hypothesis about the effectiveness of implementing experimental work on the integration of sustainable development ideas into education in the Dnipropetrovsk region.

To begin with, the authors developed a methodology for evaluating the performance of experimental educational institutions based on identifying indicators of sustainable development and education for sustainable development. Then we built a conceptual and functional model of an innovative educational institution - a school of advanced education for sustainable development. We have attached great importance to educational practices to reveal the content of the ideas of sustainable development and advanced education. These ideas were the following ones. Advanced education for sustainable development is a concept of transition of modern education to the principles of sustainable development, taking into account the main trends of social changes. The formation of the education system to ensure sustainable development provides for the transition to a model of education based on a holistic approach to human, society and nature, the unity of modern scientific knowledge and social practice, and humanistic value-worldview attitudes.

We have identified the main components of advanced education for sustainable development. These are environmental, legal, socio-economic, and moral and ethical components.

The environmental component provides for the solution of the following tasks: 1) students' assimilation of knowledge about the state of the environment, organic unity of 
human and nature, measures to preserve the integrity of natural ecosystems, ways out of the environmental crisis; 2) formation of an ecological worldview and eco-culture based on the principles of disclosure of the content and implementation of norms and principles of environmental ethics and ethics of responsibility; 3) education of patriotic feelings, love for the native land as components of environmental education for sustainable development; 4) assimilation of basic knowledge and skills regarding a healthy lifestyle, harmonization of relations between humans and the natural environment; 5) introduction to the environmental movement, development of environmental organizations at the level of school and extracurricular educational institutions of the Dnipropetrovsk region.

The legal component provides for the implementation of the following tasks: 1) students' assimilation of knowledge on the implementation of human and child rights according to the concept of sustainable development; 2) disclosure of the content of norms of democracy, legal culture of citizens, the role of the public in solving environmental and socio-economic problems; 3) involvement of kids in the processes of school selfgovernment, practical implementation of citizenship as personal and collective responsible behavior in the context of the implementation of norms and principles of sustainable development; 4) teaching children to open and free expression of their thoughts based on the implementation of the ideas of cooperation pedagogy, developing argumentation skills. The socio-economic component includes the following issues: 1) disclosure of the content of the concept of "quality life" as one of the components of the concept of sustainable development; 2) instilling skills of reasonable resource and energy consumption, rational use of consumer goods, reducing waste of raw materials; 3) introduction of social justice standards, prevention of violence and injustice in relations between children and children and adults; 4) development of a high level of social mobility of children, education of a culture of innovation and success in them, which will contribute to greater adaptation to the dynamics of life in a modern post-industrial society.

The moral and ethical component includes the solution of the following tasks: 1) the formation of humanistic values and priorities based on the idea of self-worth of each individual, his right to difference; 2) an emotional and value approach, which provides for the ability of a person to take the position of another, recognize his thoughts, at the same time, defend his own position without humiliating the dignity of another person; 3) the development of non-confrontational consciousness, focused on friendly and non-conflict activities; 4) the introduction of norms of activity pedagogy, focused on caring, active attitude to violations of the principles of sustainability, the ability to optimally respond to non-compliance with environmental and socio-economic requirements according to the priorities of sustainable development; 5) the development of a high information culture, which provides for media literacy, awareness of the problems of sustainable development, activation of critical thinking.

The main objectives of the experiment on the implementation of the ideas of education for sustainable development were as follows: 1) identification of the main ways to integrate the content of advanced education for sustainable development in the educational process; 2) selection of a package of methods and methods for diagnosing the effectiveness of assimilation of the content of advanced education by Project participants, providing diagnostics of changes in value orientations in the interests of sustainable development, the level of social responsibility of the individual; 3) the introduction of a flexible system 
of Organization of the educational process, which corresponds to modern trends in the development of the educational industry and scientifically based concepts of education for sustainable development; 4) the dissemination of school practices of education for sustainable development, increasing the level of education in the interests of sustainable development of participants in the educational process; 5) the creation of an integrated developing educational space of an educational institution based on the principles of advanced education for sustainable development, the transformation of schools into regional centers for sustainable development of their community as a driving force for the formation of civil society.

Intensive training of teachers on sustainable development was carried out on the basis of the Dnipropetrovsk Regional Institute of postgraduate teacher education (which was later transformed into the Dnipro Academy of continuing education) in the period from 2010 to 2019. In particular, 163 principals and 212 deputy principals took courses on sustainable development in 2011, 135 principals and 199 deputy principals took courses in 2012, 138 principals and 167 deputy principals did so in 2013.

The authors developed training programs and conducted courses for coordinators of pilot work on the creation and dissemination of a network of advanced education institutions for sustainable development in the region in 2011.

At the suggestion of the experiment managers, the head of the Dnipro Regional Institute of postgraduate teacher education included education issues for sustainable development in the content of advanced training courses for all categories of teachers. This has become an additional means of educational activities. The leaders of the research experiments "Advanced education for Sustainable Development" (2009-2014) and "integrating the content of advanced education for sustainable development into the educational process" (2015-2020) created a network of experimental schools (122 schools in the first experiment and 98 in the second experiment).

The authors introduced methods and technologies of advanced education, in particular, aimed at developing self-educational competencies, activating search activity, creative and social activity of the individual. We also implemented educational measures that provide for changing the value priorities and lifestyle of the individual based on the principles of sustainable development, in particular, such as a culture of eco-balanced consumption, Health-developing lifestyle, social partnership skills, tolerant behavior, social responsibility.

The authors developed and implemented experimental curricula of individual courses, special courses, electives in the direction of experimental work, as well as end-to-end training as a process of including components on education for sustainable development in the content of the invariant component of curricula.

The authors introduced the practice of permanent implementation of educational activities on education for sustainable development among teaching staff, children, youth and their parents. We have launched Regional Centers for education for sustainable development. The authors formed criteria and performance indicators of experimental work, which are indicators of sustainable development of the educational environment and indicators of education for Sustainable Development. According to the author's vision, indicators of sustainable development of the educational environment are a complex of interacting components of the educational process, which characterize the positive dynamics of 
changes in its quality and effectiveness.

The authors refer to indicators of sustainable development: 1) the quality of educational services, the content of which includes: a) the level of academic achievements of students in dynamics; b) the quality of teaching the subject by the teacher; c) the level of creation of a positive psychological climate in the school team; 2) the effectiveness of the introduction of methods and technologies of teaching and upbringing, which is: a) mastering new knowledge and skills; b) increasing the level of interest, initiative, creativity, responsibility; c) the formation of appropriate competencies; 3) the balance of the components of the educational process; 4) systematic and effective management of the educational process.

According to the author's vision, indicators of education for Sustainable Development are criteria and indicators of the nature of including the foundations of sustainable development in the content of the educational process and the level of influence of OSR on the worldview and behavior of participants in the experiment.

Indicators of education for Sustainable Development are determined by: 1) the conceptual foundations of the strategy of sustainable development, education for Sustainable Development and the model of the school of Advanced Education, which is reflected in the development concept of each specific educational institution and the program of experimental work; 2) the nature of the implementation of ideas of education for sustainable development in the educational process (content content and methods and technologies of implementation); 3) the quality of educational activities among teachers, children, youth, their parents; 4) the effectiveness of extracurricular and extracurricular activities, forms of educational work that contribute to strengthening social partnership; 5) the nature of using the resource potential for the development of an educational institution.

Identifying indicators of sustainable development of the educational environment and indicators of education for sustainable development allowed experiment managers to coordinate and significantly improve the effectiveness of experimental work of educational institutions. Based on certain indicators, experimental educational institutions were able to track the dynamics of changes in the educational environment and the impact of sustainable development ideas on the worldview and behavior of all participants in experimental activities.

Every year, the authors of the experiments conducted a survey of children, young people, teachers, and parents on sustainable development issues in order to find out changes in their value orientations. Based on this, we identified a dynamic picture of the transformation of the worldview of the participants of the experiment, carried out a comprehensive diagnosis of children and young people on their value priorities, awareness of sustainable development, and readiness for lifestyle changes.

According to the final results of the survey of teachers, sustainable development for $67 \%$ of them is the harmonious development of the individual, society and nature. $63 \%$ of teachers believe that it is possible to reduce the "ecological footprint" of an educational institution by saving energy and water and reducing the amount of waste through their disposal and rational use, through the use of health - saving technologies - $21 \%$, through landscaping of the school site and school premises-13\%. $71 \%$ believe that it is necessary to conduct educational actions on the ideas of sustainable development in society, $29 \%$ - 
it is necessary that the state, and not its citizens, take care of the preservation of resources. $54 \%$ of teachers support measures to save resources (energy, water, heat) at school and at home.

A survey of parents in the period from 2015 to 2020 to find out awareness of Sustainable Development showed that the number of those who have become more economical in using water in everyday life has increased - from 34\% to $85 \%$; those who understand the problem of environmental pollution and try to reduce the amount of garbage that the family throws out - from $14 \%$ to $67 \%$; those who hand over secondary raw materials from $17 \%$ to $59 \%$; those who consider it necessary to lead a healthy lifestyle - from 42 to $64 \%$.

Among students, the number of people who want to use water sparingly in everyday life has increased - from $38 \%$ to $76 \%$, while $20 \%$ still do not consider it important to save water.

If at the beginning of the experiment $72 \%$ of students considered the collection of secondary raw materials to be a problem of Public Utilities, and only $18 \%$ of students considered it the responsibility of every modern person, then at the end of the experiment - $28 \%$ and $67 \%$ of students, respectively. At the beginning of the study, $38 \%$ of students considered it important to take care of the environment in their daily lives, while $42 \%$ of students thought it was a matter for adults and the authorities. At the end of the experiment, $67 \%$ of students expressed concern about the environment, and 14\% of students transferred to adults and the authorities.

The implementation of the principles of education for sustainable development within the framework of educational work of higher education institutions of the region was carried out in the following forms: 1) the subject was implemented within the framework of "endto-end training of education for sustainable development", as well as elective courses ("lessons for Sustainable Development" for grades 3-4, 8 and 9 (10)), special courses ("fundamentals of energy efficiency", "Environmental Law", "Environmental Journalism" and others); 2) the intersubject form provided for the introduction of components for education for Sustainable Development by implementing the principle of integration, namely: integrated lessons and integrated items; 3) the extracurricular form provided for various forms of extracurricular and extracurricular educational work.

The methodology for implementing the principles of education for sustainable development involves shifting the emphasis in educational activities from narrow-subject to general didactic. The leaders of the experiment gave priority to developing, systemactivity approaches, the use of project technologies with the inclusion of interactive teaching methods, problem methods for the development of critical and system thinking, debate, role-playing, and business Games.

The experiment managers introduced experimental training programs for individual elective courses, special courses, and electives in the field of experimental work in many educational institutions. The methodology of" end-to-end learning " as a process of including in the content not only variable, but also invariant component of curricula components on education for sustainable development has received special support. The introduction of «end-to-end learning» made it possible to make the most of the curriculum for personal development, the formation of an ecoatropocentric worldview, as well as to change the behavior style of students in accordance with the principles of sustainable 
development.

The general didactic principles of "end-to-end learning" consist not only in providing students with information about certain problems of sustainable development, but also provide for the formation of sustainable skills in using the acquired knowledge in practice. In the long run, this also means a significant change in value priorities and worldview based on the formation of responsible, socially active, and environmentally balanced behavior. Methods and forms of conducting "end-to-end learning" in educational institutions of the Dnipropetrovsk region of Ukraine included: 1) conducting traditional lessons with the addition of individual issues related to sustainable development to the main content of educational material; 2) adjusting the content of individual topics of academic disciplines with an emphasis on a problem-based approach, personal development, game teaching methods, value attitude to the issue under study; 3) introducing non-traditional regular forms into the content of training, for example, lessons-reflections, lessons-discussions, problem seminars.

Integrated lessons and integrated disciplines are a special form of "end-to-end learning" within intersubject relationships. Integrated lessons with aspects of education for Sustainable Development were conducted by combining similar topics of several academic subjects with a focus on sustainable development issues (for example, integrated physics, chemistry and geography lessons on topics such as energy-efficient housing, household chemicals safety, the problem of garbage and urbanization, etc.). Integrated disciplines were formed by integrating individual disciplines.

The introduction of integrated lessons with aspects of sustainable development is associated with going beyond only one subject area, which significantly expands the information component of learning, transforms the aspect of studying, deepens the understanding of the subject, generalizes, systematizes the material being studied. It is also very important to reach a practical level of training, master specific social and professionally-oriented competencies. According to the method of "end-to-end learning", the authors developed and tested cards on" end-to-end learning", on the basis of which teachers of individual schools developed methodological materials and collections of tasks on" end-to-end learning", introduced a number of integrated lessons.

The main form of extracurricular activities was class hours. The authors developed the theme of class hours on sustainable development issues. Other forms of extracurricular activities included the following: holding holidays, review competitions, thematic evenings, question and answer evenings, festivals, competitions, olympiads, exhibitions, seminars, conferences. These events were built or corresponded to specific significant dates, in particular International Earth Day, International Day of tolerance, International Day of energy conservation, and were thematic or systematic in nature. Sustainable Development weeks, eco-weeks, eco-months, environment weeks, tolerance weeks, and self-government weeks are particularly common. The most common way to conduct extracurricular activities is "Sustainable Development Weeks", which have significant both educational and educational potential.

A special form of extracurricular activity is circle work. Among the interesting circle directions related to sustainable development issues that are developing in the Dnipropetrovsk region are "ecodesign", "ecotourism", "ecoteater".

A comprehensive combination of various forms of work using indicators of sustainable 
development of the educational environment and indicators of education for sustainable development allowed us to develop a system of continuing education for Sustainable Development, increase awareness of sustainable development issues, and change the worldview and behavior of all participants in the experiment.

The leaders of the experiments monitored the development of creative and intellectual abilities of students: value orientations; the level of social activity; the level of ecological culture. In particular, according to comparative data based on the results of 2011-2019 studies of students of 94 secondary education institutions, the trend of increasing a stable positive attitude of students to the environment in those classes where end-to-end learning was introduced and elective courses and special courses on education for sustainable development were taught was observed.

The entry of the Dnipropetrovsk region into the International Project "Education for sustainable development in action" was an important step towards establishing cooperation with public organizations, the purpose of which is to familiarize teachers of Ukraine with the experience, methodology and technologies of teaching students the skills and ability to build their own life and the life of a family, a local community, taking into account the needs of sustainable development. An innovative educational project "promoting a responsible lifestyle through drawing comics for Sustainable Development" was also implemented.

Scientific and methodological support for the process of implementing the principles of sustainability in the educational process was provided by a wide range of events and achievements. In order to spread the ideas of advanced education for sustainable development on the topic of experimental work, all-Ukrainian scientific and practical conferences and seminars were held annually, numerous regional exhibitions and competitions of methodological developments were organized and held.

\section{Conclusions}

The creation and holistic testing of organizational, functional and substantive aspects of the transition of the regional education system to the principles of advanced education for Sustainable Development was a common result of experimental work. The leaders of the experiment conducted monitoring studies of the effectiveness of innovative methods of advanced education for sustainable development as a means of ensuring the quality of the development of the educational environment, a comparative criterionoriented analysis of the results of the experiment using indicators of sustainable development of the educational environment and indicators of education for Sustainable Development. The leaders of the experiment carried out pedagogical analysis and correction of the model of personal competence for sustainable development in teachers, children and students in the process of changing their worldview, values and behavioral models in accordance with the principles of sustainable development. The authors selected and tested programs and methodological educational materials that will contribute to the further formation of a system of continuing education for sustainable development in the Dnipropetrovsk region. 


\section{References}

Adelman, S. (2018). The sustainable development goals, anthropocentrism and neoliberalism. In D. French \& L. Kotze (Eds.), Sustainable development goals: Law, theory and implementation (pp. 15-40). Northampton, MA: Edward Elgar.

Antunes, A., \& Gadotti, M. (2005). Ecopedagogy as the appropriate pedagogy to the earth charter process. Retrieved from http://www.earthcharterinaction.com/invent/images/uploads/ENG-Antunes.pdf

Barrable, A. (2019). Refocusing environmental education in the early years: A brief introduction to a pedagogy for connection. Education Sciences, 9(1), 61. doi:10.3390/educsci9010061

Battiste, M. (1998). Enabling the autumn seed: Toward a decolonized approach to aboriginal knowledge, language, and education. Canadian Journal of Native Education, 22(1), 16-27.

Black, C. (2017). Land-based pedagogies and the culture of schooling. In H. Kopnina and E. ShoremanOuimet (Eds), Routledge handbook of environmental anthropology (pp. 452-466). New York, NY: Routledge Earthscan.

Bonnett, M. (2007). Environmental education and the issue of nature. Journal of Curriculum Studies, 39(6), 707721. doi:10.1080/00220270701447149

Bonnett, M. (2013). Sustainable development, environmental education, and the significance of being in place. Curriculum Journal, 24(2), 250-271. doi:10.1080/09585176.2013.792672

Bonnett, M. (2015). Sustainability, the metaphysics of mastery, and transcendent nature. In H. Kopnina \& E. Shoreman-Ouimet (Eds), Sustainability: Key issues (pp. 25-39). New York, NY: Routledge Earthscan.

Engelman, R. (2013). Beyond sustainababble. In State of the world 2013 (pp. 3-16). Washington, DC: Island Press.

Fien, J. (2010). Teaching and learning for a sustainable future Paris: UNESCO. Retrieved from http://www.unesco.org/education/tlsf/

Fromm E. (2010). The heart of man : its genius for good and evil / Erich Fromm. Riverdale, NY: American Mental Health Foundation Books.

Glasser, H. (2004). Learning our way to a sustainable and desirable world: ideas inspired by arne naess and deep ecology. In P. B. Corcoran \& A. E. J. Wals (Eds.), Higher education and the challenge of sustainability: Problematics, promises, and practice (pp. 131-148). Dordrecht, The Netherlands: Springer.

Gough, A. G., \& Robottom, I. (1993). Towards a socially critical environmental education: Water quality studies in a coastal school. Journal of Curriculum Studies, 25(4), 301-316. doi:10.1080/0022027930250401

Gough, S., \& Scott, W. (2007). Higher education and sustainable development: Paradox and possibility. Abingdon: Routledge.

Gray, J., \& Curry, P. (2016). Ecodemocracy: Helping wildlife's right to survive. ECOS, 37, 18-27.

Jickling, B. (1994). Why I don't want my children to be educated for sustainable development: Sustainable belief. The Trumpeter, 11(3), 2-8.

Jickling, B., \& Spork, H. (1998). Education for the environment: A critique. Environmental Education Research, 4(3), 309-327. doi:10.1080/1350462980040306

Jogwu, C. O. (2010). Adult illiteracy: The root of African underdevelopment. Education, 130(3), 490-499.

Kahn, R. (2010). Critical pedagogy, ecoliteracy, \& planetary crisis: The ecopedagogy movement. New York, NY: Peter Lang.

Knudtson, P., \& Suzuki, D. (1992). Wisdom of the elders. Sydney: Allen and Unwin.

Kopnina, H. (2012). Education for Sustainable Development (ESD): The turn away from 'environment' in environmental education? Environmental Education Research, 18(5), 699-717. doi:10.1080/13504622.2012.658028

Kopnina, H. (2013). Schooling the world: Exploring the critical course on sustainable development through an anthropological lens. International Journal of Educational Research, 62, 220-228. doi:10.1016/j.ijer.2013.10.002

Kopnina, H. (2014). Education for sustainable development (ESD) as if environment really mattered. Environmental Development, 12, 37-46. doi:10.1016/j.envdev.2014.09.001

Kopnina, H. (2015). Sustainability in environmental education: New strategic thinking. Environment, Development and Sustainability, 17(5), 987-1002. doi:10.1007/s10668-014-9584-z 
Kopnina, H. (2016). The victims of unsustainability: A challenge to sustainable development goals. International Journal of Sustainable Development \& World Ecology, 23(2), 113-121. doi:10.1080/13504509.2015.1111269

Kopnina, H. (2018). Teaching sustainable development goals in The Netherlands: A critical approach. special issue: environmental and sustainability education in the BENELUX region. Environmental Education Research, 24(9), 1268-1283. doi:10.1080/13504622.2017.1303819

Kopnina, H. (2019). Ecocentric education: Student reflections on anthropocentrism-ecocentrism continuum and justice. Journal of Education for Sustainable Development, 13(1), 5-23. doi:10.1177/0973408219840567

Kopnina, H. (2020). Education for the future? Critical evaluation of education for sustainable development goals. The Journal of Environmental Education, 51(4), 280-212. https://doi.org/10.1080/00958964.2019.1710444

Kotze, L. J., \& French, D. (2018). The anthropocentric ontology of international environmental law and the sustainable development goals: Towards an ecocentric rule of law in the anthropocene. Global Journal of Comparative Law, 7(1), 5-36. doi:10.1163/2211906X-00701002

LaChapelle, D. (1991). Educating for deep ecology. Journal of Experiential Education, 14, 18-22. doi:10.1177/105382599101400305

McDonough, W., \& Braungart, M. (2002). Cradle to cradle: Remaking the way we make things. New York, NY: North Point Press.

Misiaszek, G. W. (2015). Ecopedagogy and citizenship in the age of globalisation: Connections between environmental and global citizenship education to save the planet. European Journal of Education, 50(3), 280-292. doi:10.1111/ejed.12138

Molina-Motos, D. (2019). Ecophilosophical principles for an ecocentric environmental education. Education Sciences, 9(1), 37. doi:10.3390/educsci9010037

Orr, D. (1994). Earth in mind: On education, environment, and the buman prospect. Washington, DC: Island Press.

Schweitzer A. (2005). Essential writings / selected with an introduction by James Brabazon. Maryknoll, N.Y. : Orbis Books.

Sitka-Sage, M. D., Kopnina, H., Blenkinsop, S., \& Piersol, L. (2017). Rewilding education in troubling times; or, getting back to the wrong post-nature. Visions for Sustainability, 8, 1-19.

Washington, H. (2018). Education for wonder. Education Sciences, 8(3), 125-139. doi:10.3390/educsci8030125 